\title{
РОЗШИРЕНА РЕАЛЬНІСТЬ ЯК НОВІТНІЙ ІНСТРУМЕНТ ЖУРНАЛІСТИКИ: ВІД ВИТОКІВ ДО СУЧАСНОСТІ
}

\author{
Анна Полісученко \\ Київський національний університет культури і мистецттв \\ вул. С. Коновальия, 36, 01133, Київ, Україна \\ e-mail:polisuchenko@gmail.com \\ https://orcid.org/0000-0002-9179-1017
}

Технології розширеної реальності активно використовують в сучасній журналістиці. Вони дають можливість передавати інформацію емоційніше, а глядачам глибше занурюватись у події. Але збільшуються й можливості маніпулятивного впливу на аудиторію. Детальне вивчення нової технології допоможе мінімізувати їі згубний вплив і сприятиме використанню у мас-медіа з більшою користю.

Ключові слова: розширена реальність, імерсивна журналістика, віртуальна реальність, доповнена реальність, інтерактивність.

Актуальність проблеми. Дослідження технологій розширеної реальності в журналістиці є достатньо новим не лише для України, але і для світової наукової спільноти. Тема є маловивченою, термінологія продовжує розширюватись і доповнюватись. Цифрові технології надають людству як переваги, так і створюють небезпеки та ризики.

У статті розглядаються як традиційні 3MI, так і цифрові медіа (блогери, влогери, стрімери, сайти та інші форми соціальної комунікації), які за широтою охоплення аудиторії часто випереджають традиційні засоби масової комунікації. Різноманітні додатки і сервіси для розширеної реальності також є частиною комунікаційної сфери, допомагають журналістам готувати матеріали і надають додаткову інформацію аудиторії.

Завдання статmі -розглянути теорію і практику становлення розширеної реальності у журналістиці, проаналізувати світовий досвід, упорядкувати термінологію, вивчити український досвід і визначити перспективи розвитку.

В наш час для того, щоб перенестись в інше місце - достатньо накласти окуляри віртуальної реальності або VR-шолом. Вперше широка аудиторія дізналась про розширену реальність у 2012 р., після виходу окулярів Google Glass. Одним із перших сервісів, який почав масово використовувати розширену реальність - Snapchat, з інтерактивними фільтрами для обробки фото. Пізніше анімовані маски з'явились і в інших сервісах: Msqrd, Instagram.

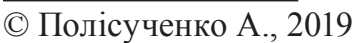


Новий виток розвитку розширеної реальності почався у 2016 р., 3 масового зацікавлення грою Pokemon Go, яка швидко підкорила світ і показала готовність користувачів виходити на вулиці у пошуках розширеної реальності і нових вражень. У 2017 р. одразу два IТ-гіганти презентували відкриті ресурси для розробки додатків i контенту з використанням доповненої реальності: ARKit від Apple та ARCore від Google.

Журналістику з використанням розширеної реальності називають «імерсивною» (журналістикою занурення, від англ. immersive). Викладення історій iз заглибленням аудиторії в сутність події завжди була основною метою журналістики. Журналістика занурення дозволяє аудиторії від першої особи побачити і почути все, що відбувається, за допомогою доступу у віртуальну версію подій, в якій точно відтворюються об’єкти, люди, передаються звуки і відчуття.

Розширена реальність позначається поняттям XR (від англ. extended reality). Вона, у свою чергу, поділяється на 3 напрямки.

VR - Virtual Reality - віртуальна реальність - комп'ютерна симуляція реальності. За допомогою технічних засобів вона відтворює світ, який передається користувачу через його відчуття: зір, слух, нюх, дотики тощо. Занурення у віртуальну реальність досягається за допомогою різноманітних гаджетів (шоломів, окулярів). Основні цілі VR: створити і покращити уявну реальність; покращити якість життя, дати можливість підготуватись до певної події, створюючи імітацію реальності, де люди можуть практикувати певні навички (наприклад, авіасимулятор для пілотів).

AR - Augment Reality - доповнена реальність - запускається на смартфонах, через камеру накладає цифровий контент поверх реального світу. Це середовище, яке у реальному часі доповнює фізичний світ цифровими даними за допомогою програмного забезпечення і різних пристроїв: планшетів, смартфонів та ін.

MR - Mixed Reality - змішана реальність - запускається у смарт-окулярах, відображає голограми поверх реального світу.

Ще нещодавно ці технології здавались науковою фантастикою. Зараз штучні світи оживають і розкриваються перед користувачами, які можуть їх контролювати. Стала досяжною глибока взаємодія з віртуальним світом.

Доповнена реальність збільшує досвід шляхом додавання віртуальних компонентів, таких як цифрові зображення, графіка чи відчуття, як новий шар взаємодії 3 реальним світом. На відміну від неї, VR створює власну реальність, повністю згенеровану і керовану за допомогою комп’ютера.

Гаджети поєднують людину з віртуальною реальністю, дозволяючи контролювати і керувати своїми діями у середовищі, імітуючи реальний світ. Доповнена реальність більше використовується у мобільних пристроях, щоб змінити вигляд реального світу, це взаємодія цифрових зображень і графіки.

Існує багато пристроїв для використання розширеної реальності: від високотехнологічних шоломів до картонних окулярів. Їхня цінова політика дуже різноманітна: від Google Cardbords (кілька доларів) до Microsoft Hololens (\$3000). Середній ціновий діапазон VR-окулярів - кілька сотень доларів. Всі шоломи і окуляри віртуальної реальності мають тенденцію до здешевлення - зростає конкуренція, збільшується ринок і кількість контенту [1]. Вартість камер, які створюють $360^{\circ}$ відео, також варіюється у межах кількох сотень доларів: Insta360 Nano/Air (\$130-\$200), Samsung Gear 360 (\$230), Kodak SP360 4K (\$900) та ін. Але є моделі і преміум-сегменту: GoPro 
Omni (\$1 500-\$5 000), Nokia Ozo (\$45 000). Основні програми для створення розширеної реальності: AutoDesk Maya, Cinema 4D (3D моделювання).

Віртуальна реальність бере початок на зорі людської цивілізації - у легендах і міфах, казках і притчах, в релігійних ритуалах. Автори книги «New media. A critical introduction» пишуть: «Що в християнській традиції є вино, як не віртуальний аналог крові Ісуса?». Т. А. Кирик пише, що в Середньовіччі схоласти називали віртуальним все, що відрізнялось від норми. Термін використовував Августин Блаженний, а шотландський філософ І. Д. Скот розширив сенс - «віртуальним» стало називатись будь-яке уявлення людини про фізичні явища. Поняття «virt» сприймалось як інформаційна копія світу. Це пояснює, чому віртуальність $є$ головною властивістю метафори, адже вона заснована на подібності.

Першим прикладом застосування віртуальної реальності вважається використання стереоскопічних окулярів у кінотеатрах. Ця технологія була запатентована ще у 90-х pp. XIX ст. - британець В. Фриз-Грін подав патентну заявку на метод виробництва стереоскопічного фільму. Установку для стереозйомки було запатентовано у 1900 р. Ф. Ю. Івом: камеру з двома об’єктивами, розставленими на відстані 1,75 дюйма (4,44см). Ефект об'ємності досягався за рахунок створення різних зображень для різних очей, знятих з різних точок. Для того, щоб бачити об'ємні предмети, необхідно використовувати обидва ока, т. з. бінокулярний зір.

У 1900 р. на Всесвітній виставці у Парижі було реалізовано ідею кругорамного кінотеатру, в якому демонструвались перші панорамні фільми. Тоді під Ейфелевою вежею побудували круглий павільйон, стіни якого слугували циліндричним екраHом.

Художник Майрон Крюгер - піонер розширеної реальності. У кінці 60-х рр. $\mathrm{XX}$ ст. він увів поняття «штучна реальність», під яким мав на увазі метод накладення рухомого зображення людини на комп'ютерну графіку. Ще будучи студентом він мріяв створити штучне середовище, яке дозволяло б глядачу переміщатись, без громіздких окулярів і перчаток з сенсорними датчиками. У 1975 р. він створив «Відеомісце» - творчу лабораторію, в якій цей метод реалізовувався за допомогою проекції на стіну. Його апарат міг відображати просте зображення - кубик, який розвертався різними гранями в залежності від ракурсу. За функціоналом це більше нагадувало AR.

Віртуальна реальність, у яку занурювалась людина, описується письменником-фантастом Станіславом Лемом. Він продовжив тему альтернативного простору, в якому може існувати людина, запущену М. Крюгером. У 1964 р. в Кракові вийшов філософсько-футурологічний трактат «Сума технології» (назва з алюзією на «Суму теології» Фоми Аквінського), в якому цілий розділ було присвячено «Фантоматиці» - галузі знань, яка вирішує проблему створення дійсності і для розумних істот нічим не відрізнялась від реальної, але підпорядковувалась би іншим законам.

Лем сформулював прообраз сучасної віртуальної реальності. Також С. Лем передбачив наукові розробки доповненої реальності, розмірковуючи над можливістю операційного втручання у людське око для модифікації зору. Така перспектива біоінженерії навіть зараз здається лякаючою, це відображає і масова культура (телесеріали «Чорне дзеркало», «Хроніка параноїка», короткометражка «Віртуальна реальність» та ін.). Разом з тим, вже почались розробки цифрового чіпу для введення у людський мозок, тому така перспектива не надто далека від реальності. 
У 1957 р. кінорежисером Мортоном Хейлігом було створено, а у 1962 р. представлено перший в історії мультисенсорний симулятор «Sensorama», який об'єднав одразу кілька функцій, прообраз 8D. Крім об’ємної картинки на широкому екрані, прилад міг відображати стереозвук, оберти, аромати, подих вітру, вібрацію. Це був певною мірою експериментальний театр. Винахід являв собою кабінет зі стереодисплеєм, динаміками, вібруючим сидінням, ароматичними сумішами для передачі запахів і феном, який імітував вітер, що б’є в обличчя - i все це на ручному управлінні, без комп'ютера (який на той час ще не було винайдено).

У 1965 р. комп’ютерний розробник А. Сазерленд випустив перший шолом віртуальної реальності «Дамоклів меч». Використання пристрою передбачало нерухомість глядача у сидячому положенні, проте вже в 70-ті рр. піонери віртуальної реальності задумались про можливість рухатись в альтернативному просторі. Результати своїх досліджень він виклав у роботі «Ідеальний дисплей», яка сприяла початку технічних і технологічних розробок у галузі обробки і виведення зображень.

У кінці 70-х рр. починається виробництво перших персональних комп'ютерів технологія віртуальної реальності отримує нову платформу для подальшого розвитку, і до неї одразу ж проявляють цікавість розробники відеоігор та індустрії розваг. У 1970 р. компанія МІТ створила перший концепт програми штучної реальності. У 1977 р. за даним концептом було реалізовано прототип - прообраз сучасного Google Мар. На трьох моніторах відображався різний інтерфейс, їх можна було обертати.

У 1984 р. В. Гібсон опублікував роман «Neuromancer», в якому вперше увів поняття «кіберпростір»- галюцинацію, яку щодня відчувають мільйони людей в усьому світі. Це графічне представлення банківських даних, які знаходяться у світовій мережі, підключених до мозку людини. Після виходу роману кіберпростором почали називати простір, створений світовою телекомунікаційною системою та іншими системами зв'язку та комунікацій.

У 1989 р. Д. Ланьєр вводить поняття «віртуальна реальність» і починається розмежування іï̈ із доповненою реальністю. Ланьєр сформулював основні принципи віртуальної реальності та перерахував пристрої, необхідні для занурення людини в віртуальний світ - як мінімум, потрібен головний дисплей і кишеньковий пристрій для управління віртуальними об’єктами. Для повного занурення необхідний ще й сенсорний костюм, що передає рухи людини у комп'ютер. Разом з головним дисплеєм можна використовувати навушники, що підсилить занурення.

Вже у 1995 р. компанія Nintendo випустила у продаж прилад VR Воу, хоча вже у 1996 р. був знятий з виробництва. В цьому шоломі були лише червоні світлодіоди. Вартість пристрою була дуже високою на той момент - один шолом коштував як 2-3 приставки. Він міг працювати і без кабелю.

Дев'яності роки стали часом стагнації індустрії розширеної реальності, що не витримала конкуренції з інтернетом. Дослідниця Б. Лорел, яка працювала в компанії Atari разом з Д. Ланьєром, у 1993 р. написала книгу під назвою «Віртуальна реальність тепер: після того, як галас скінчився».

Наприкінці 90-х рр. минулого століття розширена реальність майже на 10 років зникає зі споживчих ринків. Згадування про неї з'являються лише в художніх творах: кінофільмах «Джонні Мнемонік», «Газонокосильник», «Нірвана», «Термінатор», «Матриця»; у книгах «Віртуальна реальність (Г. Рейнгольд), «Вірт» (Д. Нун), «Лавина» (Н. Стівенсона) та ін. 
Для ЗМІ розширена реальність - можливість здивувати аудиторію, збільшити рівень занурення у матеріал, надавши доступ до всієї цифрової бази даних навіть виданню невеликого формату. Формула якісного контенту для медіа, які використовують розширену реальність, позначається трьома «І»: інформативність, інтрига, імерсивність. Завдяки імерсивності глядач більше вірить у те, що дивиться і більше співпереживає [2].

Ще у 2003 р. в США було розроблено і запущено проект Second Life - тримірний віртуальний світ з елементами соціальної мережі, у якому нині зареєстровано понад 1 млн. активних користувачів. Це не відеогра, а віртуальний простір, де можна обрати спосіб віртуального існування: участь у спільнотах, створення віртуальних товарів, будівництво, спілкування в чаті, подорожі віртуальним світом та ін. Second Life надає можливість слухати музику та інтернет-радіо, дивитись фільми і відео та ін.

Середовище у журналістиці розширеної реальності конструюється за допомогою графічних зображень у тримірних онлайн віртуальних світах, за моделлю Second Life. Глядачі у 3D-окулярах або за допомогою 3D-моніторів можуть вільно переміщатись по плану, обирати точку огляду і місце, в якому вони хочуть знаходитись, але не можуть вплинути на послідовність сцен та підсумок сюжету. У системі учасники зазвичай представлені у вигляді цифрових аватарів, вони можуть бачити власні частини тіла, тіні, відображення. Рухи віртуального тіла при цьому повністю співпадають з рухами реального людського тіла. Для підсилення ефекту присутності розробники запроваджують звуковий і відео супровід. Наприклад, у Gone Gitmo, віртуально відтвореному прототипі тюрми Гуантанамо, були використані звуки i зображення, записані в реальній тюрмі.

Facebook - одна із компаній, що найбільше інвестують у технології розширеної реальності, тестує їх на своїй великій базі користувачів. Google Maps та Google Earth також $є$ інструментами для журналістики розширеної реальності. За їхньою допомогою можна переглянути у 3D міста, місця, тури.

Twitter достатньо повільно реагував на можливості розширеної реальності, але наприкінці 2016 р. представив прямий поток $360^{\circ}$ відео через сервіс Periscope. Разом 3 тим, великі відеохостинги, такі як YouTube $360^{\circ}$ i Vimeo $360^{\circ}$, вже зараз відображають відео, зняті для віртуального середовища. Глядач навіть без спеціальних окулярів чи шоломів може на екрані комп’ютера чи телефона переглянути тримірні відео з можливістю самостійно обрати кут перегляду.

Від розвитку розширеної реальності виграє не лише сфера розваг, але й медіаіндустрія. Ще у листопаді 2015 р. американське видання «The New York Times» презентувало перший фільм «Переміщені», створений для перегляду у найдоступніших окулярах віртуальної реальності Google Cardboards. Сюжет складається 3 відеофрагментів, знятих на камеру $360^{\circ}$, без використання комп'ютерної графіки, інфографіки, а також без стендапів, які, зазвичай, пов'язують елементи фільму або пояснюють подію. Протягом всього відео присутній лайф зі звуками навколишнього середовища, голосами інших людей. Це створює ефект залучення. Протягом усього відео грає депресивна і напружена фонова мелодія.

В Україні одними із піонерів журналістики розширеної реальності стали O. Фурман та С. Полежака, які запустили VR студію по виробництву відео $360^{\circ}$ під назвою New Cave Media. Це перша українська медіакомпанія, яка розповідає журналістські історії у форматі відео $360^{\circ}$ VR. Першу VR-історію New Cave Media в Укра- 
їні зняли у Львові для «Радіо Свобода» - відео про Романа Кисляка, переселенця 3 Макіївки (Донецька обл.), який мав ДЦП і працював у Львові таксистом. Також було опубліковано серію відео про одеський сквот та історію про табір «Азовець»у Києві, яку було опубліковано у New York Times Daily $360^{\circ}$. Команда досі шукає нові формати і підходи. Наприклад, щоб зібрати якісний матеріал, вони поїхали у Арктику та відзняли багато сферичного контенту. Зараз вони працюють над розробкою енциклопедії $360^{\circ} \mathrm{VR}$ з отриманих відео.

Восени 2018 р. студія New Cave Media запустила збір коштів на ресурсі Kickstarter на документальний VR-фільм про події на Євромайдані, «Aftermath VR: Euromaidan». Команда зібрала $\$ 10000$, як і планувала. Фільм розповідає про трагічні події 20 лютого 2014 р. Автори проекту відновили в віртуальній реальності місці тих подій: Майдан Незалежності і вул. Інститутську. «Глядачі пройдуть шляхом, яким йшли протестувальники. Вони дослідять історію завдяки архівним кадрам, відеороликам з очевидцями у форматі $360^{\circ}$ і відсканованим артефактам», - говориться у описі проекту. «Aftermath VR: Euromaidan» $є$ одночасно інтерактивним документальним фільмом і віртуальним музеєм під відкритим небом.

Компанія MonticolAR при підтримці кіностудії FILM.UA та анімаційної студії Animagrad запустила перший масштабний AR-квест у Києві на основі мультфільму «Викрадена Принцеса: Руслан і Людмила». Для участі необхідно було завантажити додаток, після чого на Facebook-сторінці гри з'являлось повідомлення про розташування міток з героями, які треба було знайти і поділитись фото з героєм, що «ожив», у себе на сторінці у Facebook чи Instagram. Переможець отримував грошовий приз.

Ще один вид соціальної комунікації за допомогою розширеної реальності імерсивний театр (театр занурення). Його ще називають театром-бродилкою, він схожий на екскурсію 3 аудіогідом. Глядач там - не пасивний учасник, який може задрімати у кріслі, а повноправний герой. Дрес-код в імерсивному театрі відрізняється від традиційного: зручне взуття і одяг замість громіздких помпезних вечірніх нарядів.

Імерсивна вистава-променад нового формату «Час» починається у Києві, біля Пішохідного мосту через Дніпро. Формат імерсивної вистави має на увазі повне занурення в процес; тут не вийде відсидітись у кріслі і відвідати буфет, але можна по-іншому подивитись на Київ і на себе. Між глядачами і сценою стираються межі, вони стають одним цілим. Акторами стають випадкові перехожі, а сценою - все місто. Глядачам потрібно лише вчасно з'явитись у потрібному місці, взяти з собою документи, що засвідчують особу, надягти зручне взуття, навушники і довіритись голосу.

Восени 2018 р. компанія «Uzahvati», що поставила виставу «Час», презентувала ще одну виставу-променад, «Діалоги». Кожен гість опиняється в епіцентрі того, що відбувається і сам створює свою власну виставу, на годину занурюючись в атмосферу, лишаючись наодинці з собою (хоча навкруги багато людей). «Лише навушники, прекрасна музика Д. Саратського, твої думки, питання і відповіді, красива пластика акторів, і все це в надзвичайному місці з сильною енергетикою - в національній парламентській бібліотеці ім. Я. Мудрого», - говорить одна з учасниць події.

Разом 3 тим, звичайні театри починають застосовувати технології розширеної реальності. Наприклад, Національний театр Лондона планує використовувати окуляри доповненої реальності, щоб зробити вистави доступними для всіх: під час 
вистави на екрані будуть показуватись субтитри із фразами акторів для людей із проблемами слуху, і ця технологія вже показує гарні результати. Смарт-окуляри транслюють титри у режимі реального часу через wi-fi, а спеціальне програмне забезпечення відстежує репліки акторів, звук і світло, а потім синхронізує із ними субтитри. Ці окуляри замінять оренду звичних біноклів у театрах.

Ще у 2017 р. телеканал М1 використав під час прямоефірної трансляції церемонії нагородження «M1 Music Awards» голографічні 3D-титри, вид доповненої реальності. Пізніше інші центральні українські телеканали використовували цю технологію для реконструкції подій у новинах. У 2019 р. телеканал «Наш» вперше серед інформаційних каналів запустив технологію доповненої реальності з трекінг-системою у прямоефірному мовлення під час ток-шоу. Це були голографічні динамічні 3D-титри. На ТБ доповнена реальність допомагає глядачу взяти безпосередню участь у подіях, диктор може читати новини персонально для глядача, а самого диктора можна обрати, або намалювати будь-яку форму телевізора [3].

Непідготовлена аудиторія занадто вразлива і не завжди може відрізнити віртуальний об'єкт від реального. Негативні історії можуть стати дуже важкими для людей з порушеннями вестибулярного апарату. Пристрої мають здатність відслідковувати погляд і чи дивиться людина взагалі - цим можна маніпулювати, наприклад, забороняючи перегляд контенту, якщо глядач не перегляне рекламу.

Розширена реальність не повністю заміняє традиційні новинні формати - вона наближує до історії, яка зацікавила. Для створення успішної історії з використанням $\mathrm{XR}$, журналісти мають дати можливість глядачам взаємодіяти з нею і зберігати контроль над ходом розповіді.

Новим трендом у використанні 3D-технологій у журналістиці стала об’ємна зйомка (volumetric capture). Об'єкт можуть знімати одразу кілька камер з різних боків, після чого зображення зводяться у єдиний тримірний образ. Ця технологія дає можливість журналістам переосмислити розповідь історій. $360^{\circ}$ відеоролики - чудовий спосіб проведення дозвілля, але багато фахівців не визнають їх справжньою віртуальною реальністю, оскільки з нею не можна взаємодіяти і переміщатись всередині.

Експерти Associated Press прогнозують, що 3D-контент стане звичним вже дуже скоро, оскільки технологія розвивається і стає доступнішою, в майбутньому вона може набути несподіваних форм та ідей застосування. Сюжети з імерсивним ефектом будуть створюватись з використанням традиційних журналістських методів верифікації, але будуть представлені таким чином, що глядачі зможуть долучитись до вивчення теми.

Перепонами до розповсюдження розширеної реальності у журналістиці можуть стати високі витрати на підготовку і навчання журналістів та інвестиції в обладнання - хоча воно й дешевшає щороку. Також зростають ризики створення упередженого сюжету, де журналісти повністю контролюють і моделюють навколишнє середовище. Тому журналістам потрібно розробити редакційні стандарти й етичні норми, оскільки розширена реальність стає вже мейнстрімом у створенні новин [4].

XR-додатки у соціальних мережах пропонують приблизно одні й ті самі функції: маски і переміщення персонажів у просторі. Але $є$ й більш утилітарні додатки, які приходять на допомогу журналістам. Наприклад, AirMeasure - віртуальний вимірювач відстаней і розмірів у 3D-оточенні; Google Translate дозволяє перекладати 
текст, який бачить камера, у реальному часі; Sun Seeker допомагає побачити траекторію Сонця на місцевості в будь-який день року; Google Sky Map розпізнає, які саме зірки зараз видно на небі. У мобільному сегменті зараз сконцентровані найцікавіші AR-стартапи: YouAR, 6D, Selerio, Ubiquity6 тощо.

Нині існує чимало медіа-додатків із використанням віртуальної реальності, серед яких Life VR, NYT VR, Within, The Guardian's 6x9, Jovrnalism, YouTube, ARTE360, RYOT і багато інших. Крім додатків, існують також веб-ресурси і браузери, що базуються на розширеній реальності.

Хоча VR, вірогідно, завжди буде нішевою частиною розповіді, y AR $\epsilon$ шанс стати частиною звичного споживання контенту. Накладання відео у реальному світі - це лише початок потенціалу AR. Весь контент може бути використаним на ходу за допомогою гарнітури, із записом довгих форм.

Метою якісної журналістики є створення тісного зв'язку між аудиторією та історією. Спроби комбінувати аудіо, відео і зображення в інтернеті створили те, що деякі журналісти називають «розповідь із зануренням», це призведе читача і глядача «ближче до правди» [5].

Імерсивний репортаж можна супроводжувати звуками, запахами, смаками і навіть тактильними відчуттями - саме ці деталі і супроводжують подієву атмосферу. При цьому може виникати ряд психологічних ефектів, таких як відчуття присутності, проникаючого спілкування, участі в інтерактивному середовищі [6].

Дослідження показують, що користувачі реагують на віртуальну реальність так, ніби вона відбувається насправді, не дивлячись на те, що вони знають, що це лише імітація реальності. Дослідники відзначають, що для повного занурення віртуальне середовище не обов'язково має бути фотореалістичним: ефект присутності спостерігається навіть у віртуальних середовищах, які в двовимірному просторі нагадують набір абстрактних ліній і фігур. Розширена реальність відкриває перспективи руйнування «четвертої стіни» між автором і глядачем, допомагає йому відчути себе на місці події, можливість обрати, коли і на що йому звернути увагу.

Висновки. Використання розширеної реальності в журналістиці досі знаходиться на початковій стадії, медіа не поспішають інвестувати в ці технології. Але, як показують дослідження і практика, споживач вже готовий до сприйняття контенту такого типу, тому неминучий його подальший розвиток. Тематична направленість сюжетів говорить про орієнтацію технології на міленіалів і роботу з рекламодавцями.

Інтерес користувачів і розробників до технології зростає. Найбільшого стрибка варто очікувати тоді, коли технології дозволять створити високоякісні окуляри доповненої реальності, або навіть AR-лінзи.

AR i VR у майбутньому скоріш за все зіллються в одному пристрої за прийнятною ціною. Відео $360^{\circ}$ стане ще доступнішим - кількість пристроїв, що знімають і відтворюють збільшується. Журналістика розширеної реальності стає дешевшою й технічно доступнішою, і скоро подібні проекти зможуть готувати все більше редакцій, тематичний спектр розшириться.

Технологія розширеної реальності вже в найближчому майбутньому радикально змінить вигляд журналістики. В медіа все глибше проникає досвід віртуалізації і принципи технологій з конвергентних галузей інформатики: відеоігр, інтерактивного кіно, відеоінсталяцій. 
Однією із найбільших проблем XR $є$ недостатня виробнича здатність і доступність гаджетів. Досі шоломи страждають від поганої графіки і низької роздільної здатності. Одна з технологій рендерингу передбачає максимальну деталізацію по центру дисплея, куди направлено погляд.

Реалізму XR може додати технологія передачі ароматів, але і тут є багато проблем. Наприклад, у людей може виникнути алергія. Або що робити з неприємними, чи навіть шкідливими запахами?

Експерти відзначають, що глядачі швидко втрачають інтерес до віртуальних проектів, якщо творці не дають їм більше свободи дій. Ще одним трендом розвитку технологій стане збільшення можливостей глядача у віртуальних історіях: вони стануть більш гіпертекстуальними (нелінійними), даватимуть більше поглядів на одну тему. Незабаром з'явиться нова модель VR-проектів: не разові спеціальні матеріали, a «пакети», доступні на різних мультимедійних платформах.

Треба враховувати час, проведений у віртуальності, інакше можна повністю втратити відчуття реальності. 3 допоміжного елементу вона стає правлячим фактором. За допомогою новітніх технологій певні групи людей можуть контролювати масову свідомість, впливати на неї і маніпулювати. Медіа і гаджети не завжди є благом для людства, інколи вони можуть шкодити: відбирають бажання жити в реальності, любити, проводити час із близькими без додаткових пристроїв.

B найближчі 5 років XR сильно не зміниться: стане мобільнішим, якіснішим, хмарним, дешевшим. Пристрої для прийому стануть глобальними. Буде не потрібен телевізор для прийому зображення, воно буде повсюди. Розширена реальність має великий потенціал у модернізації.

До піку розвитку сучасної електроніки ще далеко. Більшість творців контенту визнають, що хоча повноцінної XR в журналістиці ще немає, але вона з'явиться найближчим часом. Вірогідно, що відео $360^{\circ}$ стануть кроком у напрямку до справжнього VR. Наступний крок - масовий вихід розширеної реальності з розважальної сфери у інформаційний сектор.

\section{REFERENCES}

1. Пять идей доклада по виртуальной реальности, подготовленного центром цифровой журналистики Тоу / Международная журналистская сеть. 2015. - Режим доступа: https://ijnet.org/ru/story/пять-идей-доклада-по-виртуальной-реальностиподготовленного-центром-цифровой-журналистики-тоу

2. Бирюков В. А. Использование технологии дополненной реальности при конструировании контента средств массовой информации. М., 2016.

3. Федоришин Л. Доповнена реальність змінює світ: нові можливості та нові ризики // Медіакритика. 2018. - Режим доступу: http://www.mediakrytyka.info/ohlyadyanalityka/dopovnena-realnist-zminyuye-svit-novi-mozhlyvosti-ta-novi-ryzyky.html

4. Як віртуальна реальність вплине на журналістику - дослідження Associated Press // Mediasapiens. - Режим доступу: https://ms.detector.media/mediaprosvita/research/ yak_virtualna_realnist_vpline_na_zhurnalistiku_doslidzhennya_associated_press/

5. Замков А.В. О виртуальном расширении медиареальности // Медиаскоп, 2017. Вып. 3. - Режим доступа: http://www.mediascope.ru/2351 
6. Малинка В. Світ 360: чому ЗМІ закохуються в цей формат / Mediasapiens. 2016. Режим доступу: https://ms.detector.media/web/online_media/svit_360_chomu_zmi zakokhuyutsya_v_tsey_format/

\title{
EXTENDED REALITY AS A NEW INSTRUMENT FOR JOURNALISM: FROM CURRENT TO MODERN
}

\author{
Anna Polisuchenko \\ Kyiv National University of Culture and Arts \\ 36 Ye. Konovalets Street, 01133, Kyiv, Ukraine \\ e-mail:polisuchenko@gmail.com \\ https://orcid.org/0000-0002-9179-1017
}

Extended reality technologies are actively used in modern journalism. They give the opportunity to transmit information more emotionally. But the possibilities of manipulative influence on the audience also increase. A detailed study of the new technology will help minimize its harmful effects and make the use of the media more useful.

The article investigates the theory and practice of the formation of extended reality in journalism, analyzes the world experience, organizes terminology, examines Ukrainian experience and determines the prospects of development.

Both traditional media and digital media (bloggers, vloggers, streamers, sites, and other forms of social communication) are considered, which are often ahead of the traditional media of the broader reach of the audience.

The extended reality in the near future will radically change the look of journalism. In the media both the terms of production of content and its consumption change simultaneously, which transforms the journalism of extended reality into one of the most important branches of the media industry.

The media is increasingly penetrating the virtualization experience and the principles of creative technologies from convergent branches of computer science: computer simulation, video games, interactive cinema, video installations. Although these technologies have indirect implications for extended reality journalism, they are involved in the production of extended media reality, and their impact is increasing rapidly.

One of the biggest problems with XR is still the lack of gadgets. By the peak of the development of modern electronics is still far. Most creators of the content admit that although full XR in journalism is not yet, but it will appear soon. It's likely that the $360^{\circ}$ video will be a step towards the true VR. The next step is mass exodus of extended reality from the entertainment sector to the information sector.

Key words: extended reality, immersive journalism, virtual reality, augmented reality, interactivity. 